\title{
Kvalita výuky fyziky - případy začínajících učitelů
}

\author{
Vojtěch Žák, Jana Martínková \\ Univerzita Karlova, Matematicko-fyzikální fakulta
}

\begin{abstract}
Abstrakt: Strategickým cílem výzkumu, jehož součástí je tato empirická studie, je přispět k výzkumu kvality výuky, a prohloubit tak porozumění kontextu kvality výuky. Výzkumné otázky byly stanoveny takto: Které parametry kvality jsou typické pro výuku vybraných začínajících učitelů fyziky? Které faktory ovlivňují kvalitu výuky vybraných učitelů? K zodpovězení těchto otázek byl zvolen smíšený př́stup. Základním výzkumným plánem byla případová studie. $V$ rámci kvantitativní části byl využit výzkum ex post facto a data byla sbírána na základě pozorování výuky. V kvalitativní části byla data získána na základě polostrukturovaných interview. Výzkumný vzorek sestával ze čtyř začínajících učitelů fyziky, kteři vyučují na gymnáziích. Výzkum popisuje a rozkrývá kvalitu výuky těchto pedagogů. Ukázalo se, že některé parametry byly u zkoumaných vyučujících naplněny obdobným způsobem, např. často a kvalitně byl realizován výklad, byly využívány matematické prostředky a naproti tomu nebyla zařazována heuristická metoda. Výuka se naopak lišila mimo jiné $v$ četnosti zařazování experimentů, práci s textem a dále $v$ podpoře aktivního učení žáků. Byly identifikovány jak oborově specifické, tak oborově neutrální, ale i další faktory ovlivňující kvalitu výuky fyziky. $Z$ výzkumu je patrné, že kvalitu výuky konkrétního vyučovacího oboru (fyziky) je nutné nahližet ze širší perspektivy.
\end{abstract}

Kličová slova: výzkum fyzikálního vzdělávání, kvalita výuky, začínající učitel, kontext vzdělávání, pozorování, př́padová studie

\section{The Quality of Physics Teaching - Cases of Novice Teachers}

Abstract: The strategic goal of the research, including this empirical study, is to contribute to the search for the teaching quality and to deepen the understanding of the context of the teaching quality. The research questions were posed as follows: What are the quality parameters that are typical of teaching of selected novice teachers of physics? Which factors influence the teaching quality of the selected teachers? To answer these questions, a mixed method research design was used. A case study was chosen as the basic research plan. An ex-post facto research was chosen as the design of the quantitative part of the research, and the data was collected using the method of pedagogical observation. Regarding the qualitative part, the data was gained using semi-structured interviews. The research sample consisted of four novice physics teachers, teaching in Czech grammar schools. The presented research describes and uncovers the quality of their teaching. The study revealed that some of the observed parameters were fulfilled in a similar way regarding the particular teachers, for example the frequency and quality of the realized lecturing, the use of mathematical means, or no use of the heuristic method. The teaching process differed, for instance, in the frequency of conducting experiments, the work with text, or the support of the active learning of the pupils. Several domain-specific, domain-general and other factors influencing the teaching quality were identified. This research shows that it is reasonable to look at the teaching quality from a wider perspective.

Keywords: physics education research, quality of teaching, novice teacher, context of education, observation, case study 
74 Strategickým cílem výzkumu, jehož součástí je tato studie, je přispět ke zkoumání kvality výuky, a prohloubit tak zejména porozumění kontextu kvality výuky. ${ }^{1}$ Jak naznačuje již název studie, pozornost bude omezena na kvalitu výuky konkrétního vzdělávacího oboru - fyziky.

Téma této studie může být chápáno jako oblast umístěná v průniku několika polí. Jedním z nich je kvalita (ve) vzdělávání, dalším výuka fyziky, třetím pak fenomén začínajícího učitele. Tato tři pole jsou do značné míry velmi rozdílná, nesouměřitelná. Zatímco první oblast se vyznačuje velkým rozpětím od makroúrovně (např. kvalita vzdělávacího systému jako celku) až po mikroúroveň (kvalita konkrétní výukové interakce atd.), oblast výuky fyziky je na první pohled jasně ukotvena specifickým vzdělávacím obsahem, fyzikou, který je ve výuce komunikován. Učitele pak můžeme vnímat jako personifikaci, která prostupuje a spoluvytváří dvě dřive zmíněná pole. Je zřejmé, že tento náhled na téma studie není jediný možný; pokusíme se přesto zasadit je právě do tohoto rámce.

\section{Teoretická východiska}

\subsection{Kvalita (ve) vzdělávání}

Pojem kvalita (ve) vzdělávání je součástí struktury tvořené mnoha dalšími pojmy, což je zřejmé z koncepčních prací jak ze zahraničí (např. Reynolds, 1995; Terhart, 2000), tak z českého prostředí (mj. Janík, 2012; Janík \& Chvál, 2012; Janík et al., 2013; Slavík et al., 2014, 2015). Nebudeme zde reprodukovat nebo interpretovat poznatky vztahující se k tomuto tvrzení (odkažme kupř. na Janíka et al., 2013, s. 18-22), ale upozorněme speciálně na základní hladiny kvality (ve) vzdělávání, které se vztahují k vnější organizaci školního vzdělávání: kvalita vzdělávacího systému, kvalita školy a kvalita výuky (Posch, 1999). Výše uvedené hladiny a procesy v nich probíhající nejsou samozřejmě disjunktní, vzájemně nezávislé a nelze je chápat ani tak, že jedna je striktně podmnožinou další. Přesto se domníváme, že tato jednodimenzionální struktura (jedna z více možných) dává alespoň hrubou představu o zakotvení kvality výuky (jednotlivých oborů) v síti dalších fenoménů, které do ní promlouvají.

\subsection{Kvalita výuky fyziky a dalších vzdělávacích oborů}

Specifické zaměření našeho zájmu na výuku fyziky je dáno tím, že prezentovaný výzkum je součástí oborovědidaktické reflexe, konkrétně didaktickofyzikální. Omezení se na určitý vzdělávací obor provádíme $v$ souhlasu s konceptem obsahově zaměřeného př́stupu ke studiu procesů ve výuce, ke studiu její kvality (přehledově Slavík \& Janík, 2012).

1 Tato studie vznikla na základě spoluautorčiny diplomové práce obhájené na Matematicko-fyzikální fakultě Univerzity Karlovy (Martínková, 2016). 
Možné komponenty a charakteristiky kvalitní výuky různých oborů (včetně fyziky) přehledově shrnují a diskutují Janík, Lokajíčková a Janko (2012). Na základě analýzy teoretických i empirických výzkumů (publikovaných v monografiích a recenzovaných periodikách, zejména $z$ oblasti přírodovědného a matematického vzdělávání) sdružují komponenty a charakteristiky do čtyř okruhů: organizace a řizení třídy - využití času, přiměřené tempo, strukturovanost; zprostředkování cílů a obsahů - jasnost, strukturovanost, soudržnost; učební úlohy - kognitivní aktivizace; podpůrné učební klima - konstruktivní práce s chybou, adaptivita výukových postupů. Jak autoři upozorňují (tamtéž, s. 28), otázku, čím se má vyznačovat kvalitní výuka, lze řešit nejen výzkumně, ale také na základě osobní empirie zkušených učitelů. $V$ této studii je využit přístup, který v sobě zahrnuje obě tyto cenné cesty; k pozorování výuky fyziky a usuzování na její kvalitu je využit nástroj, který byl zkonstruován na základě výzkumného šetření mezi experty, mimo jiné zkušenými učiteli (podrobněji dále a v odkazech z podkapitoly 2.2).

Ke konceptualizaci kvality výuky bývá v rámci jednotlivých oborů školního vzdělávání přistupováno v podstatě dvojím způsobem (Janík et al., 2013, s. 29-33). Někteří autoři zdůrazňují oborově specifické charakteristiky kvality výuky, jiní se zaměřují na charakteristiky oborově neutrální. V oblasti zkoumání kvality výuky fyziky operují s obecnými charakteristikami například Fischer, Reyer a Trendel (2004). Důležitou roli spatřují ve výukovém prostředí a v různých výukových cílech. Př́kladem přístupu, kdy jsou zdůrazněny oborově specifické prvky, je východisko Žáka (2008). Na základě expertního šetření provedeného mezi odborníky z pedagogiky, obecné didaktiky, didaktiky fyziky a fyziky byly formulovány parametry kvality výuky fyziky, které zahrnují jak oborově neutrální charakteristiky, mj. osobnost učitele, práce s textem, tak právě charakteristiky specifické pro fyziku, kupř. experimenty, abstrakce (podrobněji Žák, 2006, s. 32-40, 2008, s. 62-64). Hranice mezi těmito dvěma skupinami charakteristik je ale nejednoznačná, např. provádění experimentů a využívání matematických prostředků je specifické nejen pro fyziku, ale i další přírodovědné obory. Jako př́klad přístupu, kdy na základě obecnějšího modelu kvality výuky byl vytvořen model kvality výuky fyziky, můžeme uvést př́istup Fischera et al. (2014, s. 21-23), kteři vyšli z modelu Helmkeho (2006).

K oborově specifickým charakteristikám výuky a její kvality se váže poznatek, že zprostředkování obsahu určitého oboru (např. fyziky) žákům mưžeme sledovat ve dvou fázích - onto- a psychodidaktické transformaci (přehledově kupř. Janík, 2009). Je třeba tedy připustit, že do kvality výuky určitého oboru promlouvají obě tyto transformace, tj. jak metamorfóza oborových obsahů do obsahů kurikulárních, tak transformace kurikulárních obsahů do obsahu výuky. Jak bude zřejmé i z dalšího, zaměříme se zejména na kvalitu výuky úžeji spojenou s učitelem, tj. spíše s psychodidaktickou transformací, nicméně je důležité vnímat utváření kvality výuky také v kontinuu oborový obsah - kurikulární obsah - obsah výuky, což částečně odpovídá výše zmíněnému rozpětí vzdělávací systém, škola, výuka.

Je zřejmé, že výzkumníci zabývající se empiricky kvalitou výuky daného oboru musí nakonec využít určitý „seznam“ charakteristik, komponent, parametrů apod., 
76 které jsou považovány (např. v rámci určitého modelu kvality výuky) za relevantní. To na jedné straně přispívá $k$ žádoucí operacionalizaci, na druhé straně to vede k omezením, jak co do hloubky, tak šîrky zkoumání kvality výuky. Za podstatné proto považujeme věnovat pozornost interpretaci výzkumných zjištění a obezřetnost při formulování zevšeobecňujících soudů o „celkové“ kvalitě dané výuky.

\subsection{Kvalita výuky v souvislosti se začínajícími učiteli}

Na základě některých výzkumů můžeme soudit, že je oprávněné asociovat kvalitu výuky spíše s učiteli a jejich pưsobením než př́mo s celými školami (Day, 2012, s. 10). Zaměěení na učitele a jím vedenou výuku vidíme jako aktuálně důležité také v souvislosti s návrhem kariérního systému pro učitele. ${ }^{2}$ Výzkumný zájem o učitele fyziky se $v$ české didaktice fyziky objevuje již řadu desetiletí. Např́klad Fenclová (1982, s. 6-28) uvádí výchovu a vzdělávání učitelů fyziky jako jednu z osmi základních problémových oblastí didaktiky fyziky. Autorka mimo jiné akcentuje potřebu zkoumat vlastnosti učitele, jeho př́pravu a dalši vzdělávání. I když je zřejmé, že se výzkum $v$ didaktice fyziky (at' už domácí, nebo v mezinárodním physics education research) v současné době zaměřuje spíše na procesy žákovského učení (Lin, Lin, \& Tsai, 2014, s. 1359-1360), didaktickofyzikální diskuse se snaží problém učitelů přesto alespoň dílčím způsobem tematizovat (např. bilanční konference věnovaná 50 letům didaktiky fyziky v ČR - Lepil, 2007; dále kupř. Dvořák, Kekule, \& Žák, 2012, s. 147).

$\checkmark$ souladu s obecně přijímaným poznatkem, že počáteční léta kariéry mohou být kritickým momentem v profesi učitele a mohou mít dalekosáhlé následky, např. i na délku kariéry, pak obracíme pozornost konkrétně k začínajícím učitelům (srov. Píšová, 2013, s. 67). Ze specifických problémů (někdy až ohrožení) začínajících učitelů, které byly identifikovány $v$ různých výzkumech, můžeme podle Janíka et al. (2017, s. 7-8) upozornit na následující: začínající učitelé mohou v souvislosti se vstupem do profese prožít tzv. šok z reality, dále u nich může dojít $k$ tzv. syndromu vyhoření (souvisí mj. s pracovní a časovou zátěží, nedostatkem sebedůvěry, stanovováním nerealistických cílů), existuje větší pravděpodobnost jejich odchodu z profese. Z hlediska pedagogicko-didaktické perspektivy je pro začínající učitele typické nejprve zaměření se na sebe, obsah výuky, návody do výuky, na konkrétní výkony a až později se jejich pozornost přesouvá $k$ žákovi, jeho potřebám a celkovému vnímání procesů výuky (Janík et al., 2017, s. 6; srov. Fuller, 1969; Berliner, 1995).

Téma začínajícího učitele fyziky se $v$ poslední době $v$ domácím prostředí vynořuje mimo jiné v souvislosti s nedostatkem učitelů (at' už skutečným, či jen vnímaným). Jak uvádí Píšová a Hanušová (2016), je právě nedostatek učitelů jedním z faktorů ovlivňujících kvalitu vzdělávání. Je zpưsoben mimo jiné výše naznačeným odchodem učitelů z profese nebo přechodem na jinou školu, tzv. drop-outem. Velmi ohroženou profesní skupinou jsou přitom začínající učitelé (učitelé-novicové). Nedostatek učitelů je zřejmě rozdílný v případě různých skupin učitelů, např. se liší pro různé

2 Více k souvisejícímu pojmu standardizace profese učitele (včetně historického exkurzu) viz Rýdl (2014) a Spilková (2016). 
aprobace. Jak vyplývá z mimořádného šetření k dopadům novely zákona o pedagogických pracovnících (MŠMT, 2015), z pohledu škol je za dlouhodobě nedostatkovou považována právě učitelská aprobace na fyziku (mezi obory se umístila jako druhá nejvíce nedostatková, a to po anglickém jazyce).

Zdá se, že v případě některých vzdělávacích oborů je nedostatek učitelů disponujících příslušnou aprobací zpưsoben také aktuálně nízkým počtem absolventů příslušných oborů na fakultách připravujících budoucí učitele. Malý zájem žáků středních škol o učitelství fyziky (a klesající úroveň nastupujících studentů do tohoto oboru) uvedla jako jeden z problémů fyzikálního vzdělávání v ČR třetina didaktiků fyziky oslovených v nedávném expertním šetření (Dvořák, Kekule, \& Žák, 2015, s. 147).

\subsection{Smysl a cíle výzkumu}

Obecně můžeme smysl zkoumání výuky začínajících učitelů vidět několikerý. Pro pracoviště, které jim poskytlo počáteční vzdělání, může být užitečné zjišt’ovat, jak je toto vzdělání uplatněno $v$ praxi a jaké problémy výuku provázejí. I když může prezentovaný výzkum postihnout jen úzkou část reality (bude patrné zejména z jeho metodologie), nelze vyloučit jeho potenciální přínos pro oblast vzdělávání v makroměřítku - pro vzdělávací systém. Přinosem je ale také fakt, že učitelům zapojeným do výzkumu může být na základě výzkumu poskytnuta systematická zpětná vazba k jejich výuce. Připomeňme postřeh Janíka et al. (2011, s. 51), že učitelé jsou při výuce typicky profesionálně osamělí, což znamená nemožnost dělit se o právě prodělávanou zkušenost. Profesionální dialog ale mohou rozvinout díky hospitacím. ${ }^{3}$

V návaznosti na strategický cíl je cílem této studie zjistit, jaké parametry kvality má výuka vedená vybranými začínajícími učiteli fyziky a které faktory ovlivňují kvalitu výuky fyziky vybraných učitelů.

Jako výzkumné problémy byly v souladu s výše uvedenými cíli formulovány následující otázky:

- Které parametry kvality jsou typické pro výuku vybraných začínajících učitelů fyziky? (hlavní výzkumná otázka)

- Které faktory ovlivňují kvalitu výuky fyziky vybraných učitelů?

(vedlejší výzkumná otázka)

Výzkumná zjištění týkající se prvního výzkumného problému jsou nejprve usporádána v podkapitolách 3.1 a 3.2, kde jsou uvedena kvantitativní data charakterizující kvalitu výuky vedenou jednotlivými učiteli fyziky. K syntéze s kvalitativními zjištěními dochází v podkapitole 3.3 , která má ambici podat poměrně plastický obraz vystihující výuku. Výsledky vztahující se k druhému výzkumnému problému prezentuje podkapitola 3.4 .

3 Empirický výzkum prezentovaný $v$ této studii se ovšem přínosům uvedeným $v$ tomto odstavci prímo nezabývá. 
Z metodologického hlediska byl k řešení výzkumných problémů použit smišený př́istup. Základním výzkumným plánem byla př́padová studie (konkrétně vícečetná, srov. Merriam, 2009, s. 49-50). V souladu s požadavky kladenými na př́padovou studii byla snaha o (viz Yin, 2003, s. 13-14):

- nahližení př́padu (výuky vedené jednotlivými učiteli, přesněji: kvality jejich výuky) jako integrovaného systému;

- zkoumání kvality výuky učitelů $v$ co nejpřirozenějším prostředí;

- využití více zdrojů a metod ke sběru relevantních dat.

Míra respektování a konkrétní naplnění těchto požadavků budou zřejmé z následujícího. Požadavek zkoumání daných případů $v$ přirozeném prostředí došel svého naplnění tím, že za výzkumný plán kvantitativní části (částečně řešící první výzkumný problém) byl zvolen výzkum ex post facto, při kterém byla data sbírána na základě pozorování. $V$ rámci kvalitativní části (řešící jak první, tak druhý výzkumný problém) bylo jako metoda sběru dat použito polostrukturované interview. ${ }^{4}$

Pokud jde o časové hledisko, byl ve smyslu Creswella a Planové Clarkové (2006) výzkum uspořádán sekvenčně; kvantitativní sběr dat (pozorování) byl následován rozhovory (kvalitativní sběr dat). Data zjištěná oběma těmito př́stupy pak byla spojena a byl vytvořen popis jednotlivých př́padů (podkapitola 3.3). Druhý výzkumný problém, spiše doplňkový, byl řešen pouze kvalitativně. Výzkum tak vyústil v kombinaci kvantitativního a kvalitativního přistupu na různých úrovních (Tashakkori \& Teddlie, 1998).

Jako hlavní výzkumný plán byla zvolena případová studie zejména z toho důvodu, aby bylo možné hlouběji rozkrýt kvalitu výuky fyziky a její kontext (některé aspekty kontextu). Je žrejmé, že při zkoumání jen několika případů 5 musíme mít na zřeteli omezení při př́padném zobecňování výzkumných zjištění. Na druhou stranu mưžeme uvést, že bude-li zjištěna určitá variabilita i u omezeného počtu př́padů, pak u většího počtu případů bude bud' stejná, nebo vyšší. Zkoumání byt' jen několika případů má pak ten smysl, že ukazuje v tomto ohledu minimum existující variability.

\subsection{Vybrané př́ípady a postup jejich zkoumání}

Zkoumána byla výuka čtyř učitelů fyziky na gymnáziích ve školním roce 2015/2016. Jedná se o dostupný výběr učitelů, kteři absolvovali na Matematicko-fyzikální fakul-

4 Zatímco interview jsou v mezinárodním prostředí v oblasti physics education research využívána poměrně často, použití pozorování je zřejmě výrazně méně frekventované (Žák, 2016, s. 22). Interview je typicky kombinováno s dalšími metodami sběru dat (zejména dotazníkem, didaktickým testem, ale právě i pozorováním; tamtéž, s. 23) a má mimo jiné tu výhodu, že umožňuje vhodnou volbou otázek velmi flexibilně zacílit získávání informací požadovaným směrem, rozkrýt informace vytěžené dalšími metodami a ověřit nebo relativizovat další výzkumná zjištění.

5 Př́padem zde spíše než učitelem rozumíme výuku jím vedenou, respektive kvalitu této výuky (podrobněji Záa, 2014b, s. 64). 
tě Univerzity Karlovy a které můžeme považovat za začínající. ${ }^{6}$ Základní informace

o učitelích jsou následující7:

- učitel Ondřej - absolvent prezenčního magisterského studia učitelství fyziky - matematiky pro SŠ (a také doktorského oboru didaktika fyziky a obecné otázky fyziky), vyučuje 6 . rokem;

- učitelka Klára - absolventka prezenčního magisterského studia učitelství fyziky - matematiky pro SŠ, vyučuje 2. rokem;

- učitel Jakub - absolvent prezenčního magisterského studia učitelství fyziky pro SŠ v kombinaci s odbornou fyzikou, vyučuje 2. rokem;

- učitel Matěj - absolvent prezenčního magisterského studia teoretické fyziky a kurzu vyučování všeobecně vzdělávacího předmětu fyzika, vyučuje 2 . rokem. ${ }^{8}$

Výzkum měl tyto podstatné části:

- Pozorovatelka byla postupně zacvičena při pozorování a posuzování pěti vyučovacích hodin fyziky. Zacvičení probíhalo tak, že výuku sledovali nezávisle na sobě jak pozorovatelka, tak zacvičený výzkumník. Nezávisle na sobě výuku posoudili pomocí výzkumného nástroje a potom společně diskutovali rozdíly $v$ hodnocení. $\checkmark$ debatách se zejména upřesňoval význam slovního vymezení škál jednotlivých parametrů kvality výuky. Z pěti pozorování se u tří jednalo o sledování videozáznamu vyučovacích hodin, následující dvě hodiny byly pozorovány v reálné výuce. Výsledkem bylo dosažení procenta shody mezi posuzovateli srovnatelného s předchozími výzkumy. Zatímco v dřivějším výzkumu (podrobněji Žák, 2006, s. 69-72) byla zjištěna naprostá shoda $v$ přibližně $56 \%$, shoda s rozdílem 1 stupně ve $27 \%$, s rozdílem 2 stupňủ ve $2 \%$, s rozdílem 3 stupňů v $0 \%$ a neshoda v $15 \%$ př́padů, během zacvičení bylo dosaženo těchto hodnot (ve stejném pořadí): $63,27,0,0$ a $10 \%$.

- Zacvičená pozorovatelka (dále: výzkumník) pozorovala ve školním roce 2015/2016 osm vyučovacích hodin u každého z učitelů. Celkem tedy výzkumník pozoroval 32 vyučovacích hodin. Učitelé nebyli seznámeni s tím, na co přesně bude pozorování zaměřeno (aby tomu nepřizpůsobovali výuku).

- Na základě pozorování výzkumník vyplnil záznamový arch použitého standardizovaného nástroje (podrobněji podkapitola 2.2 ).

- Výzkumník provedl s jednotlivými učiteli polostrukturovaná interview. ${ }^{9}$

6 Mezi ně byl zahrnut také učitel, jehož praxe byla v době výzkumu již pětiletá. Vedl nás $\mathrm{k}$ tomu jednak jeho zájem se výzkumu účastnit a dále také fakt, že čtyři roky vyučoval jen na přibližně poloviční úvazek.

7 Jména učitelů jsou ze zřejmých důvodů smyšlená.

8 V rámci výběru zkoumaných učitelů byla snaha o diverzitu. Mezi učiteli jsou jak absolventi výlučně učitelství, tak odborné fyziky ( $v$ kombinaci s učitelstvím), učitelé na plný i částečný úvazek, žena i muži. Přesto není adekvátní výsledky výzkumu široce zobecňovat. Byla také snaha zapojit do výzkumu učitele, kteří mají již alespoň roční zkušenost $s$ výukou.

9 Na základě zkušeností z předchozích výzkumů (Žák, 2008, 2014b) byly během interview pořizovány dotazujícím se výzkumníkem odpovědi respondenta písemně; rozhovory nebyly zvukově nahrávány. Vzhledem k tomu, že rozhovor navazoval na předem strukturovanou reflexi zprostředkovanou pozorovacím nástrojem, považujeme tento prístup za adekvátní. 
80 - Dále byla propojena kvantitativní a kvalitativní zjištění (vzešlá z pozorování a interview).

- Na základě pozorování a rozhovorů byly identifikovány faktory ovlivňující kvalitu výuky fyziky vybraných učitelů.

Pozorování ve výuce učitelů probíhala během většiny daného školního roku a interview byla uskutečněna po jejich skončení. Výzkum tedy celkově probíhal paralelně (souběžně $u$ všech učitelů). Pro tento postup jsme se rozhodli zejména $z$ toho důvodu, že výzkumná zjištění týkající se kvality výuky vedené začínajícími učiteli fyziky nám nejsou z domácího ani mezinárodního prostředí známa; jde tedy spiše o prvotní zmapování výzkumného pole. V případných navazujících výzkumech lze uvažovat o sériovém výzkumu - výzkum prvního případu, na základě výsledků vyhledání dalšího případu (s cílem prohloubit první výzkumná zjištění), výzkum druhého prípadu atd.

\subsection{Pozorování kvality výuky fyziky (kvantitativní část)}

K pozorování a posuzování kvality výuky fyziky (první výzkumný problém) byl použit standardizovaný nástroj s ratingovým systémem V. Žáka $(2006,2008)^{10}$. Nástroj zahrnuje 26 parametrů (indikátorů) kvality výuky fyziky, které byly vygenerovány na základě expertního šetření (Žák, 2006, s. 32-40, 2008, s. 62-65). Tento nástroj je založen na kriteriálním záznamu umožňujícím předem strukturovanou reflexi (srov. Slavík et al., 2015). Nástroj zahrnuje jak oborově neutrální charakteristiky, tak charakteristiky specifické pro fyziku.

\section{Metodologie hodnocení četnosti výskytu parametrů kvality (viz podkapitola 3.1).}

Četnost výskytu byla rozdělena do tř́i intervalů (stejně viz Žák, 2014b, s. 66):

- nízký výskyt - od 0 do 33 \% (včetně) vyučovacích hodin - označeno jako 1 (tabulka 1);

- střední výskyt - od 34 do 66 \% (včetně) - označeno jako 2;

- vysoký výskyt - od 67 do $100 \%$ - označeno jako 3.

Četnost výskytu je uvedena jen u parametrů (viz první sloupec v tabulce 1), u kterých má význam tento údaj uvádět (vynechány byly zejména parametry s nízkou reliabilitou, podrobněji viz Žák, 2014a, s. 71), a parametry, které jsou pozorovány automaticky, tj. jejich škály neobsahují možnost $\mathrm{N}$ - „parametr nebyl pozorován“).

10 Tento nástroj byl nedávno poměrně podrobně popsán (Žák, 2014a, s. 69-71), proto zde uvádíme jen jeho nejpodstatnější charakteristiky. Je dostupný z http://kdf.mff.cuni.cz/ zak/vyuka.php, v sekci „výzkum a vývoj v didaktice a pedagogice“. 
Metodologie hodnocení aritmetických průměrů na škálách parametrů (viz podkapitola 3.2).

Určení aritmetických průměrů na škálách jednotlivých parametrů bylo provedeno následujícím způsobem: Stupňům škály, které jsou označeny jako - -, -, +, ++, byly přiřazeny hodnoty $-3,-1,+1$ a +3 , které mimo jiné vyjadřují, že škálu považujeme za ekvidistantní11. Pro každý parametr byl vypočítán aritmetický průměr a ten byl následně zaokrouhlen $\mathrm{k}$ nejbližší definované hodnotě. $\mathrm{V}$ tabulce 2 jsou uvedeny symboly - -, -, +, ++ pro parametry, jejichž četnost výskytu v pozorované výuce byla vyšší než 33 \% (u ostatních je uvedeno „nedef.“). Jedná se tedy o parametry, u nichž je v tabulce 1 označena četnost jako 2 nebo 3, a dále ty, jejichž četnost je automaticky 100 \% (není u nich definována možnost N). Pokud nebylo možné zaokrouhlit aritmetický průměr jednoznačně $k$ jediné $z$ hodnot $-3,-1,+1,+3$, např. hodnotu 2 , je v tabulce 2 uvedena odpovídající dvojice symbolů, tj. kupř. +, ++.

\subsection{Rozhovory s učiteli (kvalitativní část)}

K obohacení výzkumných zjištění (spíše kvantitativní povahy) získaných na základě pozorování a posuzování výuky s využitím výše uvedeného nástroje byla provedena polostrukturovaná interview s učiteli. Tyto učitele považujeme za do jisté míry reflektivní praktiky, kteří se nad svojí výukou zamýšlí a hodnotí ji, a to za účelem jí lépe porozumět a zlepšovat. Na rozdíl od předchozího obdobného výzkumu (srov. Žák, 2014a, s. 77, 2014b, s. 63) nelze předem usuzovat, že by byla reflektivní kompetence zkoumaných učitelů příliš rozvinuta; navíc se jedná o začínající učitele. $\mathrm{Na}$ druhou stranu na základě osobní znalosti konkrétních učitelů zapojených do výzkumu bylo možné předpokládat, že určitou mírou reflektivní kompetence disponují. Model reflektivní kompetence (a jeho elementy) rozvíjený mnoha autory již desítky let (např. Schön, 1983; Goodman, 1984; Pollard, 1998; Korthagen et al., 2001) tak i zde může zřejmě přinést určitý vhled do řešené problematiky.

V první části interview (vztahující se k prvnímu výzkumnému problému) byly učitelům pokládány otázky, které měly pomoci rozkrýt důvody a okolnosti, proč má učitelova výuka zjištěné charakteristiky (proč se v ní ne/naplňují určité parametry). Různým učitelům byly kladeny rozdílné dotazy ohledně zjištění vzešlých z pozorování a z použití výše uvedeného nástroje. Jako př́klady otázek mưžeme uvést například: Ve vaší výuce byla pozorována výborná pracovní atmosféra. Jakým způsobem se vám toho daři docílit? Jak ji udržujete? Proč poměrně často využíváte ve výuce práci s textem? Proč je to podle vás dưležité? Považujete experimentování ve výuce fyziky za důležité? Z jakého důvodu?

11 Předpokládáme, že po sobě jdoucí stupně škály jsou od sebe stejně vzdálené (lineárně rozmístěné), tj. přechodu mezi libovolnými dvěma sousedními stupni škály přiřazujeme stejnou váhu. 
82 Výzkumníkem písemně zaznamenané odpovědi byly přepsány tak, aby doplnily údaje zjištěné pozorováním (viz dále podkapitoly 3.3 a 3.4 ).

\section{Výsledky}

\section{1 Četnosti výskytu parametrů kvality}

Relativní četnosti výskytu parametrů charakterizujících výuku čtyř učitelů fyziky jsou uvedeny $v$ tabulce 1 . Parametry jsou formulovány tím způsobem, že vyšší četnost jejich výskytu může být obecně považována za pozitivnější než jejich nižší četnost. $Z$ tabulky 1 je zřejmé, že $v$ některých parametrech je výuka vedená jednotlivými učiteli velmi podobná a jsou $v$ ní dosaženy bud' vysoké četnosti výskytu (1.1 fyzikální odbornost, 2.1 výklad, 2.5 matematický model, 2.6 abstrakce, 2.9 struktura poznatků, 3.1 zájem studentů, 3.6 aktivita studentů, 3.7 nároky na studenty, 3.8 využití hodnocení) nebo nízké četnosti ( 2.2 heuristická metoda, 3.4 ostatní předměty, 3.5 umění, kultura). Ve zbývajících parametrech se výuka učitelů (posuzováno četností jejich výskytu) vzájemně lišila (např. 2.3 experimenty, 2.10 práce s textem). Je také patrné, že ve výuce vedené Klárou jsou dosahovány nejvyšší četnosti výskytu parametrů ve srovnání s ostatními učiteli (zejména s Matějem). Tento velice hrubý pohled na kvalitu výuky je $v$ dalším textu doplňován.

Tabulka 1 Relativní četnost výskytu parametrů (rozdělená do intervalů)

\begin{tabular}{lcccc}
\hline Parametr & Klára & Jakub & Matěj & Ondřej \\
\hline 1.1 fyzikální odbornost & 3 & 3 & 3 & 3 \\
1.4 využití pomůcek & 2 & 2 & 1 & 2 \\
2.1 výklad & 3 & 3 & 3 & 3 \\
2.2 heuristická metoda & 1 & 1 & 1 & 1 \\
2.3 experimenty & 2 & 1 & 1 & 2 \\
2.5 matematický model & 3 & 3 & 3 & 3 \\
2.6 abstrakce & 3 & 3 & 3 & 3 \\
2.9 struktura poznatků & 3 & 3 & 3 & 3 \\
2.10 práce s textem & 2 & 2 & 1 & 1 \\
3.1 zájem studentů & 3 & 3 & 3 & 3 \\
3.3 propojení s praxí & 3 & 3 & 2 & 3 \\
3.4 ostatní předměty & 1 & 1 & 1 & 1 \\
3.5 umění, kultura & 1 & 1 & 1 & 1 \\
3.6 aktivita studentů & 3 & 3 & 3 & 3 \\
3.7 nároky na studenty & 3 & 3 & 3 & 3 \\
3.8 využití hodnocení & 3 & 3 & 3 & 3 \\
4.1 vyjadřování žáků & 3 & 3 & 2 & 3 \\
\hline
\end{tabular}




\subsection{Aritmetické průměry na škálách parametrů kvality}

Aritmetické průměry na škálách parametrů (přesněji: stupně --, -, +, ++, které jsou nejbliže $k$ aritmetickému průměru) jsou shrnuty $v$ tabulce 2 . Parametry a jejich škály jsou formulovány tak, že větší aritmetický průměr (vyšší stupeň škály) může být považován za pozitivnější. $Z$ tabulky 2 je patrné, že ve výuce učitelů obecně dominují pozitivní stupně $(+,++)$ nad negativními $(--,-)$. Výuka jednotlivých učitelů (nahlíženo aritmetickým průměrem na škálách) se $\mathrm{v}$ jednotlivých parametrech obecně liší (jen výjimečně jsou ve výuce všech učitelů zaznamenány obdobné aritmetické průměry - 2.5 matematický model, 3.7 nároky na studenty). Obdobně jako v př́padě četnosti výskytu parametrů je zřejmé, že ve výuce vedené Klárou jsou dosahovány nejvyšší aritmetické průměry, zatímco u Matěje nejnižší.

Tabulka 2 Aritmetický průměr na škálách parametrů

\begin{tabular}{lcccc}
\hline Parametr & Klára & Jakub & Matěj & Ondřej \\
\hline 1.1 fyzikální odbornost & ++ & ++ &,+++ & ++ \\
1.2 osobnost učitele & ++ & ++ & + & ++ \\
1.4 využití pomůcek & + & + & nedef. & + \\
2.1 výklad & ++ & ++ & + & ++ \\
2.2 heuristická metoda & nedef. & nedef. & nedef. & nedef. \\
2.3 experimenty & ++ & nedef. & nedef. & ++ \\
2.5 matematický model & ++ & ++ & ++ & ++ \\
2.6 abstrakce & ++ & + & + &,+++ \\
2.9 struktura poznatků & ++ & ++ & + & ++ \\
2.10 práce s textem & + &,+++ & nedef. & nedef. \\
3.1 zájem studentů &,+++ & + & + & + \\
3.3 propojení s praxí &,+++ & + & + & + \\
3.4 ostatní předměty & nedef. & nedef. & nedef. & nedef. \\
3.5 umění, kultura & nedef. & nedef. & nedef. & nedef. \\
3.6 aktivita studentů &,+++ & + & + & + \\
3.7 nároky na studenty & + & + & + & + \\
3.8 využití hodnocení & ++ & + & + & + \\
4.1 vyjadřování žáků & ++ & ++ & + & + \\
4.2 kultivace vztahu & ++ & ++ & + & + \\
4.3 pracovní atmosféra & ++ & ++ & + & + \\
4.4 aktivní učení & ++ & + & + & + \\
\hline
\end{tabular}




\subsection{Př́pady kvality výuky jednotlivých učitelů - propojení kvantitativních a kvalitativních zjištění}

Následující text zprostředkovává propojení výše uvedených údajů o kvalitě výuky, které jsou spíše kvantitativní povahy (podkapitoly 3.1 a 3.2), s informacemi, jež byly získány na základě interview s učiteli (spíše data kvalitativní povahy). Interview vedená s učiteli se orientovala jednak na parametry, jejichž (ne)naplnění bylo typické pro výuku daného učitele, jednak byl v rozhovoru věnován prostor dalším tématưm, která se ukázala jako potenciálně důležitá ( $v$ souvislosti s kvalitou výuky). $\mathrm{V}$ tomto smyslu je strukturován následující text.

\section{Případ učitele Ondřeje (0.) - fyzikálního experimentátora, který kultivuje vztahy.}

O. vyučuje šestým rokem, přičemž první čtyři roky vyučoval na poloviční úvazek $z$ důvodu doktorského studia na MFF UK. Třída, ve které probíhalo pozorování, není podle 0 . $\vee$ ničem specifická $v$ porovnání $s$ ostatními tř́dami, ve kterých pưsobí. Jedná se o septimu osmiletého gymnázia, ve které výuka fyziky probíhá dvakrát týdně - ve středu od 12.40 hodin a ve čtvrtek v poněkud nezvyklou nultou hodinu, od 7.10 hodin. Na brzkou ranní výuku reaguje 0 . tak, že do těchto hodin připravuje více demonstračních experimentů ( $i$ ty, které by se více hodily do středeční výuky), a to z motivačních důvodů. Zároveň je dohodnuto, že písemné práce budou zadávány zpravidla také mimo tuto ranní hodinu (domluva i s rodiči žáků). $V$ této tř́dě byla pozorována výuka elektřiny a magnetismu, což je podle 0 . pro žáky obtižné učivo.

O. má vysoké hodnocení u parametrů z oblasti komunikace a výchovy (především 4.1-4.3). Pokud jde o kultivaci vztahu a pracovní atmosféru (obojí ++), musel se 0. na začátku svého působení $v$ této tř́dě o nastavení dobrých vztahů jak mezi žáky navzájem, tak mezi jím a žáky aktivně zasadit. Když 0 . tuto tř́du před pěti lety přebíral, byl ostatními učiteli upozorňován, že se jedná o neklidnou tř́du, že jsou „rozjetí“ a že minulý vyučující u nich výuku nezvládal. ${ }^{12}$ Pokud někdo při výuce nedovoleně komunikuje, 0 . ztiší svůj hlas, příp. má zkušenost, že žáky utiší jejich spolužáci.

Co se týká metod výuky, využívá často a na vysoké úrovni výklad $(2.1 ; 3,++) .0$. tvrdí, že si nedokáže představit jinou metodu, pomocí níž by ve výuce stihl probrat veškeré požadované učivo. Při výkladu se snaží sdělit žákům daný poznatek nejprve jednoduše, pak ho žákům přesně nadiktuje a nakonec ho rozebere podrobně. Jeho výuka se dále vyznačuje poměrně častým realizováním kvalitních experimentů $(2.3 ; 2,++)$. Učitel zařazuje jednak speciální vyučovací hodiny, které obsahují větší množství experimentů, a to před Vánoci a koncem školního roku, jednak v rámci

12 Je zajímavé, že třída, která byla vnímána učiteli jako problematická, byla předána tehdy začínajícímu učiteli. 
určitých témat a ročníků podle svých slov experimentuje naopak méně (např. kinematika v kvintě). Smysl zařazování experimentů do výuky vidí jednak v možnosti motivovat žáky (podle 0 . žáci oceňují především experimenty s překvapivým vyvrcholením a pozornost jim žáci věnují, zejména dělá-li experimentální show), jednak je tak podle O. možné demonstrovat, že probírané učivo odpovídá reálnému fungování světa. Dále se domnívá, že žáci tak mohou dospět k poznání, že učivo vyložené v učebnici je oproti realitě prezentováno zjednodušeně. O. pak vysvětluje důvody, proč je reálný jev složitější.

Pokud jde o práci s textem $(2.10 ; 1)$, 0 . ji do vyučovacích hodin nezařazuje; zadává ji jako domácí úkol, např. přes víkend nebo na jarní prázdniny, a to především kvưli tomu, aby měl při školní výuce více času na ostatní učivo. Úkolem žáků bývá prostudovat si př́slušnou kapitolu v učebnici, udělat si poznámky a vyřešit úlohy. Ve škole potom O. zkontroluje vypracování domácího úkolu a okomentuje jednotlivá žákovská zpracování (kupř. poukáže na žáka s výborně splněným úkolem a na žáka, který úkolu nevěnoval dostatek času). O. pak pomocí rozhovoru zjišt’uje, jak žáci učivu porozuměli, a nakonec shrne, co je důležité a co bude od žáků vyžadovat. 0 . se domnívá, že žáci pochopili, že je výhodné úkoly vypracovávat, protože mají následně prokázat příslušné znalosti při zkoušení. S textem dále pracují žáci na nižším stupni gymnázia, kterým 0 . zadává referáty a prezentace. Ty mají sloužit k rozšírení a doplnění učiva. Většinou se týkají fyzikálních zajímavostí (např. optických klamů, Leksellova gama nože, laseru, slunečních elektráren). O. využívá pro zpestření výuky také promítání obrázků, videí s experimenty, které nelze v učebně provést (kupř. startování letadla), a vlastních animací (využívá v tomto znalostí a dovedností, které získal během studia na MFF UK, včetně doktorského studia).

Ve výuce byly často a vhodně využívány matematické prostředky $(2.5 ; 3,++)$. V souvislosti s tím učitel uvádí, že na nižším stupni gymnázia se ve výuce soustředí především na prokázání výskytu daného fyzikálního jevu v přírodě (zejména experimentem), na vyšším stupni se pak spiše orientuje na kvantitativní stránku (veličinové rovnice a výpočty). Ve výuce se mu také dařilo rozvíjet abstraktní představivost žáků $(2.6 ; 3,+,++)$. O. uvádí, že většinou nejprve zavede pojem definicí, pak uvede príklady ze života, které se snaží vtipně podat. Z důvodu přibližení abstraktních pojmů žákům zařazuje do výuky již zmíněné fyzikální experimenty.

Pokud jde o souvislosti fyziky s ostatními předměty $(3.4 ; 1)$, parametr nebyl pozorován. Podle 0 . je upozorňování na mezipředmětové vazby nicméně důležité, pokud se tyto vazby týkají dalších přírodovědných oborů. Třeba při tématu oko vyžaduje po žácích, aby si na výuku fyziky zopakovali příslušné učivo biologie. Pokud jde například o dějepis, omezuje se 0 . na uvádění přibližných časových údajů a připouští, že menší propojování zde může souviset s tím, že dějepis nepatří mezi jeho oblíbené obory. Nicméně v rámci propojování fyziky s uměním a kulturou $(3.5 ; 1)$ se učitel snaží ve výuce zmiňovat osobnosti vědců, zařazovat zmínky o filmech, ve kterých lze poukázat na zajímavý fyzikální jev apod. V této škole jsou každý rok pořádány pro žáky projektové týdny, v jejichž rámci loni 0 . vedl projekt na téma fyzika ve filmech. 
Případ učitelky Kláry (K.) - podněcovatelky k učení, která oceňuje pokrok žáků.

K. je učitelkou druhým rokem; od začátku má plný úvazek. Pozorovaná třída je podle K. specifická tím, že se jedná o 1 . ročník vyššího gymnázia se sportovním zaměřením, tedy o tř́́du, ve které má většina žáků kvưli tréninkům individuální studijní plán. Podle K. to znamená, že tyto žáky škola (ani fyzika) spíše nezajímá, jejich hlavní prioritou je sport. Ze dvou týdenních hodin fyziky typicky alespoň $v$ jedné chybí. $K$. tvrdí, že žáci nemají na učení čas a že většina se ani učit nechce. Výuka fyziky zde probíhá v pondělí od 14.35 hodin a ve čtvrtek od 8.55 hodin. Na začátku školního roku se $\mathrm{K}$. podle svých slov snažila pondělní výuku vzhledem $\mathrm{k}$ odpolední hodině přizpůsobovat, např. písemné práce byly soustředěny pouze na čtvrtek. $V$ ten den však bývá hodně žáků uvolněno z výuky ze sportovních důvodů. Nakonec se tedy výuka liší podle $K$. především tím, $v$ jaké učebně probíhá, přičemž jedna učebna je vhodnější na experimentování a promítání, zatímco druhá je lépe přizpůsobena pro psaní písemných prací.

Klářina výuka má podobné charakteristiky ve čtvrté oblasti parametrů jako Ondřejova (viz tabulka 2). Obdobně i zde panovala výborná pracovní atmosféra $(4.3 ;++)$, naprostá většina žáků pracovala, reagovala na podněty učitelky. Žáci se $\mathrm{k}$ sobě navzájem i $k$ učitelce chovali slušně (kultivace vztahu, 4.2 ; ++). K. se domnívá, že spolupráce žáků s učitelem závisí také na tématu výuky - projeví se, co žáky zajímá. $K$. si myslí, že má přirozenou autoritu, a zároveň si je vědoma, že si kázeň zajistila také zadáváním trestů za vyrušování (kupř. napsat ručně třístránkovou úvahu na téma sport a fyzika). Oproti 0 . i dalším učitelům vyniká navíc Klářina výuka v parametru aktivní učení $(4.4 ;++)$. K. se domnívá, že je to způsobeno i tím, že umí odlehčit výuku vtipem (K. při řešení úlohy napsala na tabuli: „Už to ani mě nebaví.“) a že se chová k žákům osobně (otázka položená žákům: „Jakou rychlostí musíme vykopnout Vojtu, aby se dostal do vesmíru?").

Pokud jde o metody a formy výuky, K. často a na vysoké úrovni využívá výklad $(2.1 ; 3,++)$. Pozitiva výkladu spatřuje $K$. zejména $v$ uspořádanosti. Velmi dbá na diktování strukturovaných poznámek žákům do sešitů. Pokud zařadí diskusi nebo skupinovou práci, tak výkladem vše na konci shrne. Výklad kombinuje ještě s dalšími formami a metodami - samostatnou prací, studentskými prezentacemi, heuristickými rozhovory, heuristickými experimenty, demonstracemi a prací s textem. Co se týká experimentů $(2.3 ; 2,++)$, tak $v$ této třídě zatím $\mathrm{K}$. podle svých slov př́liš pokusů do výuky nezařazovala, protože nebylo co $v$ souvislosti s probíranou látkou demonstrovat. Pokud ale vyučuje např́klad elektřinu, provádí pokusy každou hodinu. Smysl experimentování je podle $K$. především v aktivizaci žáků, kteří při něm zjistí, „že se něco děje“. I při realizaci demonstračních experimentů se učitelka snaží žáky do výuky více zapojovat, kupř. při experimentu na Ohmův zákon jeden žák mění napětí, druhý odečítá hodnoty a diktuje je třetímu žákovi, který je zapisuje na tabuli. Podle učitelky se tímto způsobem rozvíjí spolupráce mezi žáky, kteří mají navíc pocit užitečnosti. 
Co se týká práce s textem $(2.10 ; 2,+)$, v polovině Klářiných hodin žáci pracovali bud' $s$ ofoceným textem, nebo $s$ textem přímo $v$ učebnici. Do práce se zapojovala většina žáků; typicky K. formuluje k textu otázky, pak žáci pracují samostatně a poté text diskutují. Podle K. je důležité, aby se žáci ve škole naučili používat při studiu knihy; při domácí prrípravě si pak podle K. vzpomenou na situace ze školní výuky a dokážou se $v$ učebnici lépe orientovat. $V$ některých třídách také kopíruje texty z populárních knih ( $\mathrm{z}$ důvodu motivace žáků). S textem (včetně učebnic) $\mathrm{K}$. ve výuce pracuje také $z$ toho důvodu, aby byl určitý doklad pro rodiče o tom, co se ve výuce dělo.

Klářina výuka vynikala rozvíjením abstraktní představivosti žáků $(2.6 ; 3 ;++)$. Žáci měli typicky $v$ této souvislosti věcné dotazy a K. byla schopna jim přibližit daný pojem na konkrétních a analogických jevech. Tato její snaha zřejmě souvisí s faktem, že propojuje fyziku s praxí, se životem $(3.3 ; 3,+,++)$ a využívá zájmu žáků $(3.1 ; 3$, $+,++)$. K. si na jednu stranu uvědomuje, že pokud se žáci nebudou dále fyzikou zabývat (např. při vysokoškolském studiu), nebudou si pravděpodobně dále pamatovat určitý zákon nebo vztah. Na druhou stranu je optimistická v tom, že když žáci pochopí daný jev, který se týká života, praxe, tak fyzikální poznatky s ním spojené nezapomenou a pomůže jim to nad příslušnými ději přemýšlet. K. mimo jiné využívá zkušenosti žáků ze sportovních disciplín, kterým se věnují. K. sama sice nesportuje, ale při prrípravě výuky se radí s kolegyní fyzikářkou, která má ke sportu blízký vztah.

Pokud jde o souvislosti fyziky s ostatními předměty $(3.4 ; 1)$, ve dvou pozorovaných hodinách $\mathrm{K}$. poukázala na mezipředmětovou vazbu, kterou dokázala žákům vhodně přibližit. K. tvrdí, že propojování fyziky s ostatními předměty považuje za důležité, nicméně vnímá pro něj ve výuce málo času, a proto nestíhá uvádět tolik mezipředmětových vazeb, kolik by považovala za vhodné. Konkrétně se snaží propojovat fyziku především s chemií (např. elektrolýza), biologií (kupř. elektromagnetické záření, jeho vnímání živočichy) a dějepisem (objev atomu apod.). Ačkoli v pozorované výuce nebylo tematizováno propojování fyziky s uměním a kulturou $(3.5 ; 1)$, snaží se K. podle svých slov o to třeba poukázáním na nereálnost určité situace ve filmu. Učitelka považuje upozorňování na tyto vazby za důležité hlavně kvůli těm žákům, kteři se z hlediska zájmu orientují na umění a historii. Mohou tak alespoň na chvíli pocítit, že také oni mohou ostatní žáky obohatit svými znalostmi i při výuce fyziky. K. se domnívá, že to má vliv na sebevědomí žáků a že to mưže sloužit jako krátkodobá motivace.

K. se velmi dařilo podporovat aktivitu žáků $(3.6 ; 3,+,++)$. Nejvíce z pozorovaných učitelů žáky vtahovala do problematiky, vyvolávala a řídila diskuse. $\mathrm{K}$. se domnívá, že aktivním zapojováním do výuky jsou žáci podněcováni jednak k přemýšlení, jednak je to nutí dávat pozor (souvislost s parametry 4.2 a 4.3). Ze všech pozorovaných učitelů nejlépe využívala hodnocení k motivaci $(3.8 ; 3,++)$. Pohotově hodnotila výkony žáků, zejména kladla důraz na hodnocení pokroku jednotlivých žáků. Hodnotila je nejen známkami, ale i slovně. Oceňovala jejich věcné nápady a zájem. K. tvrdí, že se snaží především o pozitivní hodnocení pokroku; ukazuje tím žákům, že skutečně má smysl se zlepšit, byt' třeba jen o trochu. V tomto čerpá ze zkušeností své matky-učitelky, která jí radila chválit zejména slabé žáky i za malé 
88 pokroky. K. také žáky vybízí, aby se nebáli, že udělají chybu. Na základě hodnocení pomocí použitého výzkumného nástroje můžeme Klářinu výuku považovat celkově za nejkvalitnější v porovnání s výukou ostatních začínajících učitelů (nejvyšší hodnocení v tabulkách 1 a 2).

\section{Případ učitele Jakuba (J.) - astrofyzika zabývajícího se nadanými žáky.}

J. je jako učitel zaměstnán druhým rokem a od začátku má snížený, zhruba $40 \%$ úvazek z důvodu doktorského studia na MFF UK. Vystudoval učitelství fyziky pro SŠ $v$ kombinaci s odbornou fyzikou, a má tedy aprobaci pouze na výuku fyziky. Pozorovaná třída je podle J. výjimečná tím, že třetina jejích žáků je velmi nadaných (více, než byl zvyklý při předchozí výuce na gymnáziu v okresním městě). Těmto žákům zadává práci navíc, konkrétně se jedná o referáty, které pak prezentují před tř́dou, dále úlohy navíc, navrhuje jim k prostudování odborné publikace, které si mohou během výuky číst, a snaží se je dále motivovat. Do výuky fyziky zvažuje do budoucna zařadit také skupinovou práci, kdy je $v$ každé skupině někdo $z$ těchto nadaných. Ve výuce matematiky $v$ této tř́dě se mu tato forma již osvědčila; docházelo $\mathrm{k}$ pomoci nadanějších žáků ostatním. J. se domnívá, že může $v$ této třídě žákům zprostředkovávat pokročilejší fyzikální partie, které jsou i pro něj zajímavé. $Z$ toho vyvozuje, že by mohly být poutavé i pro žáky.

Dalším specifikem výuky v této třídě je fakt, že zde J. vyučuje jak fyziku, tak matematiku. Jedná se o 1 . ročník čtyřletého gymnázia, ve kterém výuka fyziky probíhá v pondělí od 8.30 hodin a jednou za dva týdny v úterý od 10.20 hodin dvě vyučovací hodiny. Úterní výuku koncipuje J. často tak, že zařazuje úvody $\mathrm{k}$ jednotlivým tématům (aby jim mohl kontinuálně věnovat více času). Dále jsou ještě zařazovány laboratorní práce (dvě vyučovací hodiny jednou za tři týdny).

J. má obdobně jako $\mathrm{O}$. a $\mathrm{K}$. vysoké hodnocení u parametrů z oblasti komunikace $a$ výchovy (především 4.1-4.3). V porovnání s ostatními učiteli zařazuje do výuky spolu s K. také práci s textem (2.10). Ve třídě byla pozorována velmi dobrá pracovní atmosféra $(4.3 ;++)$, žáci se chovali k sobě navzájem i k J. kultivovaně $(4.2 ;++)$. $\mathrm{Na}$ druhou stranu J. uvedl, že ve výuce dané třídy vnímá určitou zvýšenou hladinu hluku. J. tvrdí, že mu to vadí jednak osobně, jednak se tak žáci podle něj vzájemně ruší. Podle J. ale není účinným nástrojem pro docílení klidu zvyšování hlasu; tvrdí, že ale obecně nezná nástroje na zjednání si klidu při výuce. Podle něj je důležité mít autoritu, čehož podle svých slov dosáhl tím, že žákům ukázal, že fyzika je zajímavá a že on jako učitel má mnoho poznatků a dovedností.

Pokud jde o metody a formy výuky, J. použivá často a na vysoké úrovni výklad (2.1; $3,++)$. Vnímá ho jako metodu, která je pro něj nejjednodušší na přípravu. Tvrdí, že by rád zařazoval i další metody, ale domnívá se, že až na výjimky neví, s čím výklad kombinovat. Na druhou stranu uvádí, že z metod a forem do výuky zařazuje také experiment, rozhovor, promítání videa, skupinovou práci, soutěž, referát a dobrovolný domácí úkol. Co se týká využívání experimentů $(2.3 ; 1)$, vidí v něm J. svůj velký 
nedostatek. Je si vědom málo častého provádění pokusů a rád by je zařazoval více. Podle něj spočívá tento problém jak v tom, že nyní vyučuje témata, ve kterých nelze provádět dostatek pokusů, tak v tom, že sám sebe považuje spiše za teoretického fyzika. Jako limit vidí také to, že ve škole není dostatek pomůcek. Další problém spatřuje $v$ tom, že se připravuje na vyučování spiše doma těsně před výukou, a často si tak nezjistí, které pomůcky jsou ve škole $k$ dispozici.

Práci s textem $(2.10 ; 2,+,++)$ J. do výuky zařazuje, ačkoli žáci nevlastní učebnice. J. vymýšlí či vyhledává fyzikální úlohy s delším slovním zadáním, $\mathrm{k}$ jejichž řešení je třeba provádět odhady hodnot fyzikálních veličin, př́p. je vyhledávat (některé údaje jsou ze zadání vynechány). Podle učitele tak žáci více využívají složitější myšlenkové operace. Důsledkem je podle něj to, že žáci začnou více uvažovat nad tím, jak daný jev, stroj apod. fungují (souvislost s propojováním s praxí, 3.3; 3,+).

Co se týká souvislostí fyziky s ostatními předměty $(3.4 ; 1)$ a propojování fyziky s uměním a kulturou $(3.5 ; 1)$, bylo by podle J. vhodné poukazovat na tyto souvislosti častěji jak $z$ důvodu neoddělitelnosti těchto oblastí v reálném životě, tak kvůli možnosti aktivizace žáků, kteři vynikají v nefyzikálních oblastech. J. tvrdí, že zde obecně naráží na nedostatek času; nicméně uvádí, že když suploval ve výuce výtvarné výchovy a dějepisu, tak se věnoval se žáky výskytu fyziky v těchto oborech (např. při výtvarné výchově žáci kreslili zatmění Slunce a učitel doplňoval fyzikální souvislosti).

Pro získání zpětné vazby (zjištování individuálních potřeb žáků) využívá J. podle svých slov dotazník, který $v$ této třídě administroval $v$ listopadu. $Z$ tohoto šetření vyplynulo, že žáci by uvítali větší systematičnost výuky a větší kázeň ve třídě. J. se $v$ tomto směru snaží o změnu.

\section{Případ učitele Matěje (M.) - teoretického fyzika vyučujícího v hluku.}

M. vyučuje druhým rokem, přičemž od začátku téměř na plný úvazek. Minulý rok vyučoval 18 hodin týdně ve dvou školách, letos se rozhodl pro jednu z nich, ve které vyučuje 19 hodin. Je vystudovaný teoretický fyzik, dva roky pracoval v Akademii věd ČR. Matějovým aprobačním předmětem je pouze fyzika, ale vyučuje i informatiku a matematiku. Tř́da, ve které probíhalo pozorování, je podle $M$. specifická tím, že pokud je rozdělena na poloviny, dávají žáci pozor a pracují, zatímco když je celá třída pohromadě, je těžké u nich udržet pozornost, žáci vyrušují (souvisí s horším hodnocením parametrů 4.3 a 4.4). Jedná se o 3 . ročník šestiletého gymnázia, ve kterém výuka fyziky probíhá ve čtvrtek od 8.00 hodin $v$ celé třídě a v úterý od 8.55 hodin, respektive od 10.00 hodin pro poloviny trrídy. ${ }^{13}$ Dalším specifikem této třídy je podle $M$. fakt, že se zde při výuce fyziky během tř́i let vystřídali tři různí učitelé.

Hodnocení Matějovy výuky je v porovnání s ostatními učiteli spíše slabší (viz tabulka 2). Určitý rozdíl byl pozorován u parametru osobnost učitele (1.2; +); i když byl M. celkem vstřícný a trpělivý, nerad např́iklad se žáky diskutoval. $S$ tím souvisí nižší

13 Pozorování bylo prováděno pouze ve čtvrteční výuce, kdy byla vyučována celá třída. 
90 hodnocení u parametrů 4.1, 4.2 a zejména 4.3, 4.4. Pokud jde o zhoršenou pracovní atmosféru (4.3; -), kupř. hluk způsobený tím, že se žáci spolu nedovoleně baví, $M$. si je toho vědom (viz výše). Uvádí, že je schopen „vykládat do mluvícího davu“, vadí mu však, že hluk může rušit některé žáky při práci. M. tvrdí, že pokud budou mít žáci dobré známky z písemných prací, což $v$ této třídě zatím podle něj platí, nebude se pracovní atmosférou více zabývat. Pozoruje, že právě dobré známky jsou pro žáky značnou motivací, čehož se snaží využívat. ${ }^{14}$ Po každé písemné práci dává další týden možnost napsat si obdobnou opravnou. Tím si podle $M$. většina žáků dostuduje nedostatky. Žákům je do klasifikace započtena vždy známka z první písemné práce a v př́padě zlepšení i z druhé.

$S$ výše uvedeným problémem souvisí také relativně slabší hodnocení parametru kultivace vztahu $(4.2 ;+)$. M. by mohl být důslednější při zabraňování opakování nevhodného chování žáků. Co se týká vyjadřování žáků $(4.1 ; 2,+)$, M. dává žákům méně prostoru k vyjadřování a stačí mu, když žáci zachytí fyzikální podstatu. Podle svých slov chce především, aby někdo odpověděl a aby si nemusel odpovídat sám (což se mu, bohužel, často stává).

Pokud jde o výklad $(2.1 ; 3,+)$, byl poměrně srozumitelný a věcně správný, občas byl ale př́liš dlouhý a někteři žáci mu nevěnovali pozornost (souvislost $s$ nižším hodnocením parametrů 4.3 a 4.4). M. tvrdí, že výklad zařazuje $z$ důvodu velkého množství látky, kterou je třeba se ve výuce zabývat, a také protože rád vykládá. Protože chce podle svých slov „jít do hloubky“, nemůže nechat žákům přiliš prostoru pro objevování (které podle $M$. někteří žáci nemají ani př́liš v oblibě). Co se týká experimentů $(2.3 ; 1)$, byly provedeny jen $v$ jedné pozorované hodině (obdobně využití pomůcek, $1.4 ; 1)$. Experimenty zařazuje spiše do úterní výuky, kdy má vždy polovinu třídy. Navíc tato výuka probíhá ve fyzikální učebně, nemusí tedy pomůcky přenášet do jiné učebny. Dalším důvodem absence experimentů bylo podle $M$. probírané učivo (mechanika), při kterém experimentuje nejméně. Na rozdíl od jiných fyzikálních oborů totiž žáci podle $M$. mají v mechanice adekvátní představy, jak experiment dopadne. Proto ji vyučuje spiše teoreticky a soustředí se na matematizaci (matematický model, $2.5 ; 3,++$ ). $M$. tvrdí, že také zohledňuje věk žáků; na nižším stupni gymnázia provádí $v$ ostatních fyzikálních oborech experiment téměř každou vyučovací hodinu. $M$. podle vlastního mínění není učitelem, jehož cílem je žáky pobavit prováděním experimentů. Podle něj je zařazení pokusu vhodné tehdy, když potřebuje ozřejmit děj, jehož výsledek žáci nevymyslí. Dále se domnívá, že je účelné experiment zařadit jako potvrzení výsledku již vyřešené kvantitativní úlohy. Úterní hodiny tak podle něj odpovídají cvičení na VŠ, zatímco čtvrteční hodiny přednáškám. Co se týká práce s textem $(2.10 ; 1), M$. ji do vyučovacích hodin nezařazuje, nicméně k přípravě na výuku mají žáci doporučenou učebnici, která byla vytvořena př́mo pro žáky tohoto gymnázia.

14 Toto učitelovo pozorování je $v$ souladu s dřivějším výzkumným zjištěním vzešlým z rozsáhlého dotazníkového šetření, ve kterém se ukázalo, že fyziku se žáci nejčastěji učí proto, že chtějí mít dobré známky (a dále, protože jejich rodiče chtějí, aby měli dobré známky). Podrobněji Kekule, Pöschl a Žák, 2008, s. 16-21. 
M. používá ve výuce (obdobně jako ostatní učitelé) na vysoké úrovni matematic-

ké prostředky $(2.5 ; 3,++)$. M. podle svých slov ukazuje využití matematiky v praxi, klade důraz na rychlé a správné počítání, na odvozování vztahů mezi veličinami, a to především z důvodu využití těchto dovedností při studiu na vysoké škole. M. tvrdí, že si uvědomuje, kteři žáci jsou nadaní ke studiu technických oborů na vysokých školách. Některým zadává k vypracování fyzikální olympiádu. Podle něj nadanější žáci, kteří se zúčastňují olympiády, s ním ve výuce paradoxně spolupracují méně; na otázky, které pokládá, odpovídají spiše ostatní.

Co se týká propojování fyziky s ostatními předměty $(3.4 ; 1)$, stejně jako u ostatních učitelů se $v$ pozorované výuce vyskytovalo sporadicky. $M$. se však podle svých slov snaží fyziku propojovat zejména s chemií, př́í. s dějepisem. Pokud jde o propojování s praxí $(3.3 ; 2,+)$, je podle $M$. vhodná již zmíněná učebnice. $M$. je ale skeptický vǔči tomu, že by mohli učitelé dopodrobna rozumět současným fyzikálním aplikacím. Podle něj je důležité zprostředkovávat (i skrytě) fyzikální principy a vědecké metody zkoumání světa.

\subsection{Faktory ovlivňující kvalitu výuky fyziky}

Na základě pozorování výuky fyziky a rozhovorů se vynořily určité faktory, které ovlivňují kvalitu výuky fyziky, příp. jsou tak alespoň př́slušnými učiteli vnímány. Pokusíme se tyto faktory prezentovat $v$ souladu s úvodní částí této studie, kde bylo zmíněno několik možných úhlů pohledu na kvalitu výuky.

Zdá se, že jedním z faktorů promlouvajících do kvality výuky je (vnímaný) nedostatek času. Ten jistě není specifickým determinantem pouze kvality výuky fyziky, ale kvality nejrůznějších procesů a produktů obecně. Objevuje se $v$ argumentacích učitelů opakovaně, $v$ různých podobách a souvisí jak s onto-, tak psychodidaktickou transformací (obtíže věnovat se veškerému učivu uloženému kurikulárními dokumenty, a to nejen do žádoucí šíře, ale i hloubky; z nedostatku času vyplývající preferování výkladu; zadávání práce s textem na doma; méně časté zařazování mezipředmětových vazeb atd.).

Za další (opět obecnější) faktor je možné považovat organizační a technické podmínky na úrovni školy, např. přizpůsobování výuky učebně (ne/vhodná k experimentování); nedostatek pomůcek (k experimentování); denní doba, kdy probíhá vyučovací hodina; absence žáků kvůli sportovním tréninkům; vystřídání více učitelů fyziky během kratší doby $v$ dané třídě.

Za faktor spojený s oborově neutrální rovinou a s psychodidaktickou transformací můžeme považovat zohlednění různých aktérů. Zmíněna byla individualita žáků (vyjití vstř́ic zájmu žáků - sport, umění, historie; žáci nadaní na fyziku; z dotazníku, který učitel nezávisle na tomto výzkumu administroval svým žákům, vyplynulo, že očekávají větší systematičnost výuky a kázeň spolužáků, což chce učitel zohlednit), ale také vliv rodičů (práce s textem má sloužit jako doklad pro rodiče, co se ve výuce odehrávalo). 
Je zřejmé, že si učitelé jako jeden z faktorů ovlivňujících kvalitu výuky, kterou vedou, uvědomují i sami sebe, svoje zkušenosti a přesvědčení (učitel se vnímá jako teoretický fyzik; učitel si uvědomuje problémy spojené s př́pravou na výuku těsně před ní; učitel se na Vš naučil vytvářet fyzikální animace; přesvědčení učitele, že jeho fyzikální znalosti mohou přispět $\mathrm{k}$ jeho autoritě; odlehčování výuky vtipem; orientace na kvalitu výsledků vzdělávání, ne na procesy - učitel neřeší zhoršenou pracovní atmosféru ve výuce; učitel přenáší metody a formy výuky typické pro vš, „přednáška a cvičeni“, do své výuky na gymnáziu).

S psychodidaktickou transformací můžeme spojit právě metody a formy výuky. Obecně je možné konstatovat, že ve sledované výuce byly využívány spíše tradiční metody výuky. Jednalo se hlavně o výklad (spiše oborově neutrální charakteristika kvality výuky). V̌̌ichni zkoumaní učitelé ho často a na vysoké úrovni zařazovali. Byl spojován jak s časovou úsporou a jednoduchostí př́ípravy pro učitele, tak i s jeho potenciálem uspořádaně prostřednictvím něj komunikovat obsah výuky. Realizace výkladu, respektive vysvětlování učiva, souvisí s jasností a strukturovaností, které jsou součástí okruhu komponent a charakteristik kvalitní výuky označovaných jako „zprostředkování cílů a obsahư“ (viz podkapitola 1.2, dále Janík et al., 2012, s. 33-37).

Za spiše oborově specifickou charakteristiku kvality výuky pak můžeme považovat experimentování ve výuce fyziky. Pokud učitelé zařazovali do výuky experimenty, pak je spojovali s možností motivovat žáky (spíše psychodidaktický rozměr), omezeně také $s$ využitím experimentů $v$ epistemologickém smyslu (experiment $k$ verifikaci, že teorie prezentovaná $v$ učebnici odpovídá reálným procesům $v$ prírodě, respektive jen $v$ určitém přiblížení).

Dalším faktorem ovlivňujícím kvalitu výuky fyziky (spiše oborově specifickým) je postavení matematiky v rámci fyziky. Je zřejmé, že výuka všech zkoumaných učitelů se vzácně shodovala $v$ tom, že $v$ ní byly matematické prostředky velmi hojně a na vysoké úrovni využívány. Jeden $z$ učitelů dokonce vnímal zařazení matematiky do výyky fyziky jako matematickou průpravu ke studiu vš.

$\checkmark$ různých souvislostech se objevoval jako faktor ovlivňující výuku a její kvalitu fyzikální obsah výuky, např. pokročilejší fyzikální partie jsou učitelem považovány za zajímavé pro žáky; na tématu výuky je závislé množství experimentů zařazených do výuky, ale i ochota žáků spolupracovat s učitelem.

\section{Závěr a diskuse}

Pokud jde o první výzkumný problém, které parametry kvality jsou typické pro výuku vybraných začínajících učitelů fyziky, můžeme říci, že se výuka vyznačovala vysokou fyzikální odborností učitelů, často a kvalitně byl realizován výklad, byly používány matematické prostředky, budována struktura poznatků a velmi se dbalo na kultivování vzájemných vztahů žáků (včetně vztahů s učitelem). Poměrně časté a kvalitní bylo také využivání zájmu žákủ, kladení přiměřených nároků na ně a využí- 
vání hodnocení k jejich motivaci. Výuka jednotlivých zkoumaných učitelů se ale také podobala naopak nízkým naplňováním jiných parametrů - nezařazováním heuristické metody, nepropojováním fyziky s jinými vzdělávacími obory a nepoukazováním na vztah fyziky k umění a kultuře. V některých parametrech se výuka učitelů vzájemně lišila - v četnosti zařazování experimentů, práce s textem a dále v kvalitě pracovní atmosféry a podpoře aktivního učení žákư učitelem.

Při řešení druhého výzkumného problému byly identifikovány jak obecnější faktory ovlivňující kvalitu výuky fyziky - nedostatek času, organizační a technické podmínky na úrovni školy, vliv různých aktérů na výuku (žáci, rodiče, sami učitelé), tak oborově neutrální faktory - využivání zejména tradičních metod výuky, ale i oborově specifické faktory - postavení experimentování a matematiky ve výuce fyziky.

Je zřejmé, že tyto faktory mají na kvalitu výuky různých učitelů obecně rozdílný vliv. Také je patrné, že nejsou vzájemně nezávislé a pravděpodobně netvoří úplný výčet vlivů na kvalitu výuky (a naopak, některým ze zmíněných faktorů může být učiteli připisován silnější vliv, než odpovídá skutečnosti). Zastavme se nyní u některých výzkumných zjištění.

Je možné namítnout, že učiteli vnímaný nedostatek času je triviálním zdůvodněním, proč nebylo realizováno to, co bylo zamýšleno. Nedostatek času, speciálně nižší hodinová dotace fyziky (především oproti stavu v osmdesátých letech 20. století), je tradičně považován i mnohými didaktiky fyziky za nepříznivou podmínku kvalitní výuky fyziky (srov. Lepil \& Svoboda, 2007, s. 32). V této souvislosti je třeba poznamenat, že možného fyzikálního obsahu (toho, co může být potenciálně transformováno do kurikula) bude vždy více, než co umožní realizovat i ty nejbohatší hodinové dotace. Problém tkví spíše v tom, co a jakým způsobem do kurikula zařadit. Přitom bychom měli jít ještě více $k$ podstatě problému a řešit otázku, co je cílem (smyslem) zařazení určitého prvku do kurikula. Jedním z výrazných omezení v konstrukci nových kurikul jsou pak zřejmě sami učitelé a didaktikové, kteři často považují vyřazení určitého tématu ( $v$ porovnání s dobou, kdy sami byli žáky) za akt degradující vzdělávací obor. Nejde ale $v$ žádném případě o prosté „vynechávání starých témat“, popř. nahrazení některých z nich tématy současné fyziky. Jde o kritickou analýzu, príp. reformu (snad dynamickou a permanentní) kurikula školské fyziky jako celku. Kritický náhled zasluhují také otázky, co žáci z fyziky budou potřebovat ve svém běžném životě, co budou potřebovat ti, kteři se fyzikou, popř. prrírodovědnými a technickými obory, budou zabývat profesně. Tyto otázky na jednu stranu výrazně přesahují zkoumanou výuku, na druhou stranu vytváří její širší kontext. Na úrovni školy je nicméně poměrně snadné provést alespoň parametrické změny kurikula, $a$ to úpravou školního vzdělávacího programu (ze zkoumaných učitelů v blízké budoucnosti má být realizováno učitelkou Klárou a jejími kolegy). To, že se učitelé konstruktivně vyrovnali s nižší hodinovou dotací fyziky tím, že velmi promyšleně redukovali učivo, je z praxe známo (Žák, 2014b, s. 77). Takzvaný nominální čas, který odpovídá stanovenému výukovému plánu, je součástí problematiky využití času v rámci okruhu komponent a charakteristik kvalitní výuky označovaných jako „organizace a řízení třídy“ (viz podkapitola 1.2, dále Janík et al., 2012, s. 29-33). Klíčové zde ale zřejmě 
94 je „aktivní učení žáka“ (srov. parametr 4.4 v tomto výzkumu a Janík et. al., 2012, s. 30), jehož podmínkou je, že žák udržuje aktivní pozornost, je duševně př́tomen. Učitelem vnímaný nedostatek času a s ním spojená časová zátěž mohou však také fatálně vyústit $v$ jeho profesní vyhoření a odchod $z$ profese (viz podkapitola 1.3).

Výuka všech zkoumaných učitelů se vzácně shodovala $v$ tom, že $v$ ní byly matematické prostředky velmi hojně a na vysoké úrovni využívány (obdobně Žák, 2008, s. 68, 2014b, s. 68-69). Důvodů $k$ tomu je zřejmě více a nejsou nezávislé, např. druhý aprobační předmět dvou ze čtyř učitelů je matematika, všichni vystudovali na matematicko-fyzikální fakultě, kde matematika tvoří páteř studia všech oborů. Existují ale i další, širší důvody. Česká školská fyzika je zřejmě v porovnání s mnoha zahraničními zeměmi tradičně více matematizována ( $v$ nich je pěstován spiše konceptuální př́stup; podrobněji ke konceptuálním testům Docktor \& Mestre, 2014). Navíc $v$ některých zemích je fyzika $v$ různé míre integrována do vzdělávacího oboru science, čímž se posiluje sepětí fyziky spiše s dalšími přírodovědnými obory než matematikou. Přitom jako možnost určitého vyrovnání se s výše zmíněným nedostatkem času bylo zkoumanými učiteli navrženo soustředit se více na kvalitativní a konceptuální stránku fyziky (např. prokazování existence jevů experimentem), a to především na úrovni ZŠ, respektive nižším gymnáziu, a kvantitativní př́stupy (veličinové rovnice a výpočty) soustředit na střední školu, vyšší stupeň gymnázia (ale i tam je redukovat). Na druhou stranu nelze tento problém řešit prostou redukcí matematické složky ve fyzikálním vzdělávání. Jak ukázaly výsledky rozsáhlého šetření v České republice, značná část těch středoškoláků, kteří zamýšli v budoucnu studovat matematiku nebo fyziku na VŠ, se chce v rámci výuky fyziky zabývat matematickými činnostmi; dokonce velmi silně mají zájem o odvozování veličinových rovnic, které typicky vyžaduje použití složitějších myšlenkových operací (podrobněji Žák, 2014c, s. 285).

Pokud jde o využití fyzikálních experimentů, ve výuce se experimentovalo průměrně často nebo méně často. Velmi časté experimentování ve výuce fyziky je spiše ojedinělé i mezi zkušenými učiteli (srov. Žák, 2008, s. 67, 2014b, s. 68). V protikladu $k$ tomu uved'me, že čeští experti uvádějí provádění fyzikálních experimentů vůbec nejčetněji jako jeden z parametrů kvalitní výuky fyziky (Žák, 2008, s. 62). Vzhledem $k$ rozličným metodám, formám a specifickým př́stupưm, $v$ jejichž rámci je možné do výuky přírodovědné experimenty zařazovat (běžnější demonstrační experimenty, nejrůznější žákovské experimenty, včetně inquiry-based science education, srov. Papáček, 2010), lze těžko zcela jednoznačně tvrdit, že častější realizace experimentů znamená kvalitnější výuku; velmi záleží na konkrétní realizaci experimentu a jeho funkčním zařazení do výuky (obdobně Bayrhuber et al., 2004; Dvořák et al., 2012, s. 329).

V souvislosti s méně častým experimentováním pak neudivuje, že zkoumaní učitelé nezařazovali do výuky heuristickou metodu, kterou lze spojit s konstruktivistickým př́stupem (a také s žákovskými experimenty). Pro porovnání uved'me, že učitelé základních škol obecně cítí potřebu konstruktivistického učení; na druhou stranu i mnozí z těchto učitelů se domnívají, že mezi nejefektivnější metody vedoucí k učení patři výklad (podrobněji Straková et al., 2014, s. 56-57). Obdobně byla spíše 
zřídka zařazována práce $s$ textem. $V$ této souvislosti je důležité zjištění, že práce s textem není na českých gymnáziích stále ještě samožrejmostí (Radváková, 2015, s. 104). Autorka (s. 105) to doplňuje zjištěním z výuky českého jazyka a literatury, že žáci se více učí o literatuře, než pracují s literaturou. Přitom $k$ zlepšení čtenářské gramotnosti žáků (tolik diskutované v posledních letech) je systematické a velmi promyšlené zařazování této metody zřejmě nezbytné.

Z pozorované výuky a provedených rozhovorů je zřejmé, že zkoumaní učitelé jak sebe, tak realizovanou výuku úzce spojují s fyzikou, s př́močarým komunikováním fyzikálního obsahu, a širši kontext výuky (včetně propojování s jinými oblastmi lidského poznání a kultury) př́liš nereflektují. Toto zjištění odpovídá období vstupu do profese, jak je nahlíženo např. Berlinerem (1995) - viz podkapitola 1.3. Nicméně se zřejmě nejedná o specifikum jen začínajících učitelů; podle Kašparové, Potužníkové a Janíka $(2015$, s. 552) se učitelé v ČR vnímají být vyučujícími zejména konkrétních předmětů, jejichž úkolem je zprostředkování př́slušného vzdělávacího obsahu. Malý přesah školské fyziky směrem ke kultuře, společnosti, genderu, filozofii, epistemologii apod. je $v$ českých podmínkách zřejmě výraznějším rysem projevujícím se i v charakteru didaktickofyzikálních publikací (srov. Kekule, 2014, s. 46).

Přes výše uvedené problematické momenty spojené s kvalitou výuky fyziky je možné kladně hodnotit, že učitelé, jejichž výuka byla zkoumána, velmi stáli o reflexi ze strany výzkumníka (koneckonců dobrovolně se výzkumu účastnili). Jsou tedy na nadějné cestě stát se reflektujícími praktiky (připomeňme mimo jiné uvědomování si diverzity žáků Klárou a Jakubem). $Z$ hlediska pracoviště, které se je snažilo $v$ rámci pregraduální př́pravy na tuto cestu připravit, je pozitivní, že způsobem naznačeným $v$ tomto výzkumu je možné získávat zpětnou vazbu od absolventů, kterou lze promítnout do vysokoškolské př́ípravy dalších učitelů (zkoumaní učitelé se také vyjadřovali $\mathrm{k}$ tomu, co by bylo vhodné do pregraduální př́pravy dále zařadit a jakým způsobem by bylo vhodné diskutovaná témata uchopit). Zdá se, že tento př́istup by mohl dynamicky korigovat př́pravu učitelů v závislosti na aktuální edukační realitě ve školách.

\section{Literatura}

Bayrhuber, H., Ralle, B., Reiss, K., Schön, L.-H., \& Vollmer, H. J. (Eds.). (2004). Konsequenzen aus PISA. Perspektiven der Fachdidaktiken. Innsbruck: StudienVerlag.

Berliner, D. C. (1995). Teacher expertise. In L. W. Anderson (Ed.), International encyclopedia of teaching and teacher education (s. 46-52). Oxford: Elsevier Science.

Creswell, J. W. , \& Plano Clark, V. L. (2006). Designing and conducting mixed methods research. Thousand Oaks: SAGE Publications.

Day, C. (2012). Efektivní učitelé a jejich vášnivé zaujetí kvalitou. Orbis scholae, 6(3), 9-26.

Docktor, J. L., \& Mestre, J. P. (2014). Synthesis of discipline-based education research in physics. Physical Review Special Topics - Physics Education Research, 10(2), 1-58.

Dvořák, L., Kekule, M., \& Žák, V. (2012). Výzkum v oblasti fyzikálního vzdělávání - co, proč a jak. Ceskoslovenský časopis pro fyziku, 62(5-6), 325-330.

Dvořák, L., Kekule, M., \& Žák, V. (2015). Didaktika fyziky včera, dnes a zítra. In I. Stuchlíková \& T. Janík (Eds.), Oborové didaktiky: vývoj - stav - perspektivy (s. 123-157). Brno: MU.

Fenclová, J. (1982). Úvod do teorie a metodologie didaktiky fyziky. Praha: SPN. 
96 Fischer, H. E., Labudde, P., Neumann, K., \& Viiri, J. (Eds.). (2014). Quality of instruction in physics: Comparing Finland, Germany and Switzerland. Münster, New York: Waxmann.

Fischer, E., Reyer, T., \& Trendel, G. (2004). Lehrer- und Schülereinschätzungen von Physikunterricht. Essener Unikate, 24, 87-95.

Fuller, F. F. (1969). Concerns of teachers: A developmental conceptualization. American Educational Research Journal, 6(2), 207-226.

Goodman, J. (1984). Reflection and teacher education: A case study and theoretical analysis. Interchange, 15(3), 9-26.

Helmke, A. (2006). Unterrichtsqualität: Erfassen, Bewerten, Verbessern. Seelze: Kallmeyersche Verlagsbuchhandlung.

Janík, T. (2009). Obsah vzdělávání. In J. Průcha (Ed.), Pedagogická encyklopedie (s. 138-142). Praha: Portál.

Janík, T. (2012). Kvalita výuky: vymezení pojmu a způsobů jeho užívání. Pedagogika, 62(3), 244-261.

Janík, T., \& Chvál, M. (Eds.). (2012). Kvalita ve vzdělávání [Monotematické číslo]. Orbis scholae, 6(3).

Janík, T., Lokajíčková, V., \& Janko, T. (2012). Komponenty a charakteristiky zakládající kvalitu výuky: přehled výzkumných zjištění. Orbis scholae, 6(3), 27-55.

Janík, T., Slavík, J., Mužík, V., Trna, J., Janko, T., Lokajíčková, V., ... Zlatníček, P. (2013). Kvalita (ve) vzdělávání: obsahově zaměřený př́stup ke zkoumáni a zlepšování výuky. Brno: MU.

Janík, T., Slavík, J., \& Najvar, P., et al. (2011). Kurikulární reforma na gymnáziích - od virtuálních hospitací $k$ videostudiím. Praha: Národní ústav pro vzdělávání.

Janík, T., Wildová, R., Uličná, K., Minaříková, E., Janík, M., Jašková, J., \& Šimůnková, B. (2017). Adaptační období pro začínající učitele: zahraniční přistupy a návrhy řešení. Pedagogika, 67(1), 4-26.

Kašparová, V., Potužníková, E., \& Janík, T. (2015). Subjektivně vnímaná zdatnost učitelů v kontextu jejich profesního vzdělávání: zjištění a výzvy z šetření TALIS 2013. Pedagogická orientace, 25(4), 528-556.

Kekule, M. (2014). Obsahová analýza klíčových témat výzkumu v přírodovědném vzdělávání. Scientia in educatione, 5(2), 40-57.

Kekule, M., Pöschl, R., \& Žák, V. (2008). Jak to vidí žáci. In L. Dvořák (Ed.), Lze učit fyziku zajímavěji a lépe? Příručka pro učitele (s. 13-50). Praha: Matfyzpress.

Korthagen, F. A. J., Kessels, J., Koster, B., Lagerwerf, B., \& Wubbels, T. (2001). Linking practice and theory: The pedagogy of realistic teacher education. Mahwah: Lawrence Erlbaum Associates.

Lepil, O. (Ed.). (2007). 50 let didaktiky fyziky $v$ ČR: sborník z konference. Olomouc: UP.

Lepil, O., \& Svoboda, E. (2007). Příručka pro učitele fyziky na střední škole. Praha: Prometheus.

Lin, T. C., Lin, T. J., \& Tsai, C. C. (2014). Research trends in science education from 2008 to 2012: A systematic content analysis of publications in selected journals. International Journal of Science Education, 36(8), 1346-1372.

Martínková, J. (2016). Kvalita výuky začínajících učitelů fyziky (Diplomová práce). Praha: MFF UK.

Merriam, S. B. (2009). Qualitative research: A guide to design and implementation. San Francisco: Jossey-Bass.

MŠMT. (2015). Analýza výsledků mimořádného šetření k dopadům novely zákona o pedagogických pracovnících. Praha: MŠMT.

Papáček, M. (2010). Badatelsky orientované přírodovědné vyučování - cesta pro biologické vzdělávání generací $Y, Z$ a alfa? Scientia in educatione, 1(1), 33-49.

Píšová, M. (2013). Teacher professional socialisation: Objective determinants. Orbis scholae, $7(2), 67-80$.

Píšová, M., \& Hanušová, S. (2016). Začínající učitelé a drop-out. Pedagogika, 66(4), 386-407.

Pollard, A. (1998). Reflective teaching in the primary school. London: Cassell.

Posch, P. (1999). Qualitätsevaluation und Qualitätsentwicklung im Schulwesen. Erziehung und Unterricht, 5-6, 326-337. 
Radváková, V. (2015). Práce s textem na střední škole. Orbis scholae, 9(3), 87-109.

Reynolds, D. (1995). School effectiveness and quality in education. In P. Ribbins \& E. Burridge (Eds.), Improving education: Promoting quality in schools (s. 11-29). London: Cassell.

Rýdl, K. (2014). Vývoj standardizace profese učitele v České republice - nekonečný přiběh? Orbis scholae, 8(3), 9-21.

Schön, D. A. (1983). The reflective practitioner: How professionals think in action. New York: Basic Books.

Slavík, J., \& Janík, T. (2012). Kvalita výuky: obsahově zaměřený přistup ke studiu procesů vyučování a učení. Pedagogika, 62(3), 262-286.

Slavík, J., Janík, T., Jarníková, J., \& Tupý, J. (2014). Zkoumání a rozvíjení kvality výuky $\checkmark$ oborových didaktikách: metodika 3A mezi teorií a praxí. Pedagogická orientace, 24(5), $721-752$.

Slavík, J., Lukavský, J., Najvar, P., \& Janík, T. (2015). Profesní soud o kvalitě výuky: předem a následně strukturovaná reflexe. Pedagogika, 65(1), 5-33.

Spilková, V. (2016). Přístupy české vzdělávací politiky po roce 1989: Deprofesionalizace učitelství a učitelského vzdělávání? Pedagogika, 66(4), 368-385.

Straková, J., Spilková, V., Friedlaenderová, H., Hanzák, T., \& Simonová, J. (2014). Profesní přesvědčení učitelů základních škol a studentů fakult připravujících budoucí učitele. Pedagogika, 64(1), 34-65.

Tashakkori, A., \& Teddlie, C. (1998). Mixed methodology: Combining qualitative and quantitative approaches. Applied Social Research Methods Series, 46. Thousand Oaks: SAGE Publications.

Terhart, E. (2000). Qualität und Qualitätssicherung im Schulsystem: Hintergründe - Konzepte - Probleme. Zeitschrift für Pädagogik, 41(4), 809-829.

Yin, R. K. (2003). Case study research: Design and methods. Thousand Oaks: SAGE Publications.

Žák, V. (2006). Zjištování parametrů kvality výuky fyziky (Disertační práce). Praha: MFF UK.

Žák, V. (2008). Zjišt'ování parametrů kvality výuky fyziky. Pedagogika, 58(1), 61-72.

Žák, v. (2014a). Kvalita výuky fyziky dvojí perspektivou - porovnání pohledů výzkumníka a učitele. Pedagogika, 64(1), 66-80.

Žák, V. (2014b). The quality of physics teaching - cases of teaching over time and in space by three teachers. Orbis scholae, 8(2), 61-82.

Žák, V. (2014c). Zájem středoškolákù o matematické činnosti ve výuce fyziky. Matematika - fyzika - informatika, 23(4), 275-286.

Žák, V. (2016). Metody sběru dat využívané didaktikou fyziky v mezinárodním prostředí. Scientia in Educatione, 7(2), 18-33.

RNDr. Mgr. Vojtěch Žák, Ph.D., Katedra didaktiky fyziky Matematicko-fyzikální fakulta, Univerzita Karlova V Holešovičkách 2, 18000 Praha 8 Vojtech.Zak@mff.cuni.cz

Mgr. Jana Martínková Gymnázium Jaroslava Heyrovského Mezi Školami 2475/29, 15800 Praha 5 jana.martinkov@seznam.cz 